\title{
REVIEW REFORMASI SISTEM PERPAJAKAN DI NORWEGIA: SUATU PEMBELAJARAN BAGI REFORMASI PERPAJAKAN INDONESIA
}

\author{
Maria R.U.D. Tambunan \\ Departemen IImu Administrasi Fiskal Universitas Indonesia
}

Alamat Korespondensi: maria.tambunan@ui.ac.id

\section{INFORMASI ARTIKEL}

Diterima Pertama

[20122019]

Dinyatakan Diterima

[01062020]

\section{KATA KUNCl:}

Tax reform, taxation system, tax administration, tax compliance, tax policy

Reformasi perpajakan, sistem perpajakan, administrasi perpajakan, kepatuhan perpajakan, kebijakan pajak

KLASIFIKASI JEL:

$\mathrm{H} 2 \mathrm{O}, \mathrm{H} 21, \mathrm{H} 22, \mathrm{H} 25$.

\begin{abstract}
ABSTRAK
This article is a critical review and as a means of lesson learned for Indonesia taxation system based on the taxation reform undertaken by Norwegian government as a member of welfare state and OECD, that is considered as a country with high tax ratio. It is also a state which has succeed to realize welfare and income distribution without distort domestic economic stabilization. In this article, it is discussed how the Norwegian government fully aware of the role of tax reform as a mandatory task to reach the state objective by optimizing taxation as instrument of social welfare, productivity improvement and stimulus to realize friendly investment environment. Several tax reform agendas such as reduction of corporate income tax, prevention on profit shifting and until the optimization of the use of big data to support the tax reform. Indonesia on its tax reform agenda which has been commenced in 1983 has transformed significantly for many aspects such as administrative affairs and the way the government to implement the tax policy. These measures have aligned with global tax trend. However, several works remain such less optimize tax ratio during the last one decade.
\end{abstract}

Artikel ini merupakan critical review sekaligus sebagai sarana pembelajaran bagi sistem perpajakan di Indonesia atas reformasi sistem perpajakan yang dilakukan oleh pemerintah Norwegia sebagai salah satu dari kelompok negara welfare state yang oleh OECD dinilai berhasil memiliki tax ratio yang cukup tinggi sekaligus mampu menciptakan pemerataan penghasilan tanpa mendistorsi kegiatan ekonomi domestik. Dalam artikel ini diuraikan bagaimana pemerintah Norwegia memahami sepenuhnya bahwa reformasi pajak merupakan suatu keniscayaan untuk mencapai tujuan negara yaitu menggunakan instrumen pajak sebagai instrumen pemerataan sosial, peningkatan produktivitas dan stimulus untuk mewujudkan lingkungan ekonomi yang ramah terhadap investasi. Beberapa agenda reformasi yang diulas seperti kebijakan penurunan tarif pajak penghasilan korporasi, pencegahan terjadinya profit shifting hingga pengoptimalan penggunaan teknologi dan big data dalam sistem perpajakan. Indonesia dalam perjalanan reformasi perpajakan sejak 1983 telah mengalami perubahan yang cukup signifikan baik dalam hal administrasi dan implementasi kebijakan pajak sesuai dengan tren reformasi perpajakan global. Namun, catatan penting dalam perjalanan reformasi perpajakan Indonesia adalah masih rendahnya tingkat kepatuhan dan masih rendahnya tax ratio Indonesia dalam kurun waktu satu decade terakhir. 


\section{PENDAHULUAN}

\subsection{Latar Belakang}

Artikel ini merupakan suatu critical review terkait reformasi sistem perpajakan di Norwegia dan bagaimana reformasi perpajakan tersebut direfleksikan dengan perjalanan reformasi perpajakan Indonesia yang telah dimulai sejak tahun 1983. Norwegia menjadi negara yang akan menjadi topik pembahasan dalam artikel ini mengacu pada laporan yang diterbitkan oleh $\operatorname{OECD}(2012,2019)$ dan European Union Commision (2013) sebagai suatu negara anggota OECD yang berhasil mengoptimalkan penerimaan pajak dan melaksanakan pemerataan penerimaan tanpa mengakibatkan distorsi yang berarti bagi kegiatan perekonomian domestiknya. Hal ini akan menjadi ulasan penting dalam artikel ini dimana langkah-langkah yang diambil pemerintah Norwegia akan diuraikan, namun tidak terlepas dari beberapa catatan penting terkait langkah-langkah tersebut. Pada akhirnya kebijakan perpajakan yang telah diimplementasikan oleh pemerintah Norwegia diharapkan dapat menjadi pembelajaran awal dalam proses perjalanan reformasi perpajakan Indonesia yang masih berlangsung hingga saat ini.

Dalam sebuah artikel yang diterbitkan oleh pemerintah Norwegia pada tahun 2018 berjudul "Better Taxation - A Tax Reform to Transformation and Growth" menguraikan mengenai reformasi pajak yang terjadi di Norwegia, peluang dan tantangan yang dihadapi pemerintah serta peran otoritas pajak atau Tax Comission dalam proses tersebut. Dalam artikel tersebut, digambarkan dengan jelas bahwa pemerintah Norwegia memahami sepenuhnya bahwa reformasi pajak merupakan suatu keniscayaan untuk mencapai tujuan negara yaitu menggunakan instrumen pajak sebagai instrumen pemerataan sosial, peningkatan produktivitas dan stimulus untuk mewujudkan lingkungan ekonomi yang ramah terhadap investasi. Dengan demikian, sistem perpajakan harus didesain dalam mencapai maksud tersebut, terutama mengingat bahwa Norwegia tidak dapat lagi bergantung pada komoditas minyak bumi dan gas. Meskipun sistem perpajakan di Norwegia telah tergolong mapan sejak dilaksanakannya reformasi pajak tahun 1992 dengan tarif yang rendah dan basis pemajakan yang luas, namun perlu untuk melakukan dan memastikan pelaksanaan reformasi secara berkelanjutan, yaitu dengan tetap menyesuaikan dengan sistem perdagangan internasional yang semakin terintegrasi.

Pemerintah Norwegia menyadari bahwa basis pengenaan pajak atas korporasi semakin mobile dan semakin mudah tergerus, sehingga sistem perpajakan harus kokoh dan mampu menyesuaikan dengan trend perpajakan internasional. Langkah yang diambil oleh Pemerintah Norwegia adalah menurunkan tarif pajak korporasi dari $27 \%$ menjadi $20 \%$, dimana penurunan tarif awal menjadi $22 \%$ pada tahun 2016-2018 terlebih dahulu, kemudian menjadi $20 \%$ dan juga menurunkan tarif pajak orang pribadi. Hal tersebut didasarkan pada pertimbangan untuk mencegah pemindahan keuntungan kejurisdiksi lain dengan tarif pajak yang lebih rendah (Oliver Denk, 2012). Potensi kehilangan penerimaan pajak yang berasal dari jenis pajak tersebut (pajak penghasilan korporasi) akan diperoleh dari jenis pemapajakan atas konsumsi, misalnya Pajak Pertambahan Nilai dan pajak atas kekayaan. Hal ini diyakini sebagai suatu pilihan yang baik, menyesuaikan dengan dinamika kegiatan ekonomi serta sangat feasible untuk dilaksanakan seperti rekomendasi dari OECD.

\subsection{Tujuan Penelitian}

Uraian diatas merupakan pokok-pokok utama terkait kebijakan perpajakan yang dipilih oleh pemerintah Norwegia sebagai bagian agenda reformasi perpajakannya. Dalam bagian berikut akan diulas lebih mendalam sistem perpajakan Norwegia pasca pelaksanaan agenda reformasinya baik dalam hal pilihan kebijakan dan pengadministrasian pemungutan pajaknya, serta berbagai catatan dalam setiap bagiannya. Selain itu, pada bagian berikutnya dalam artikel ini juga diulas perjalanan reformasi perpajakan Indonesia sejak 1983 baik dalam hal pilihan kebijakan dan administrasi/pengumpulan pajaknya. Pada bagian akhir akan diulas juga refleksi perjalanan reformasi perpajakan Indonesia dengan bercermin dengan hal yang telah dilakukan di Norwegia. Dengan uraian tersebut, akan dapat diperoleh gambaran bagaimana implementasi kebijakan selama reformasi perpajakan Indonesia dapat ditingkatkan kedepannya

\section{KERANGKA TEORI}

Selama empat dekade, kegiatan Norwegia digerakkan oleh industri Migas. Menyadari hal tersebut bukanlah sumber penerimaan yang berkelanjutan, ditambah dengan permasalahan aging population, pemerintah semakin tergerak untuk mengoptimalkan motor ekonomi lainnya diluar sektor Migas. Dalam hal ini, pemerintah juga menggunakan sistem perpajakan sebagai instrumen transformasi, diluar instrumen lainnya seperti pembiayaan dan kepemilikan sebagai sumber penggerak kegiatan ekonomi. Dengan demikian, dapat dikatakan bahwa tujuan utama dari transformasi yang diharapkan pemerintah adalah adanya produktivitas yang tetap tinggi dengan masuknya aliran modal dan tenaga kerja sebagai dampak dari penurunan beban tarif pajak efektif yang ditujukan untuk menarik investasi (IMF, 2017). Pemilihan sistem perpajakan sebagai instrumen stabilitas ekonomi semakin relevan, meskipun disisi lain terdapat kesepakatan antar anggota Uni Eropa yang membatasi penurunan tarif pajak. 
Pada dasarnya, penurunan tarif efektif pajak dilakukan hampir seluruh anggota OECD dari sekitar $50 \%$ pada tahun 1981 menjadi sekitar 25\% pada tahun 2015, seperti Swedia, Denmark dan Finlandia. Beberapa aspek pajak yang menjadi perhatian Tax Comission Norwegia terkait penurunan beban pajak efektif (i) tarif pajak yang tinggi akan menyebabkan investor untuk menginvestasikan modalnya di negara dengan tarif pajak yang lebih rendah, dengan demikian perlu melakukan stabilitas tarif pajak yang kompetitif (ii) utang dan modal diperlakukan dengan berbeda dimana cost of debt financing dapat menjadi pengurang, sementara cost of equity financing tidak dapat menjadi pengurang, (iii) tarif pajak yang tinggi akan mendorong entitas multinasional untuk memindahkan modalnya ke negara lain. Disamping aspek pajak, pemerintah Norwegia juga menyadari bahwa stabilitas politik dan kapasitas institusional pemerintah juga merupakan faktor penting dalam menarik investasi (Rubolino \& Waldernstorm, 2019). Dengan demikian, pemerintah Norwegia tetap mengupayakan optimalisasi dari faktor-faktor tersebut.

Meskipun pemerintah Norwegia mampu menawarkan lingkungan yang baik untuk investasi, adanya penarikan pajak atas kekayaan bersih sepertinya menjadi disinsentif jika dihadapkan dalam proses reformasi pajak yang cukup progresif. Hal ini menjadi tantangan tersendiri, karena terdapat pemikiran bahwa pada akhirnya pemilik modal akan membayar beban pajak yang jumlahnya cukup besar sementara pembayaran pajak tersebut tidak berhubungan langsung dengan kenaikan penghasilan yang diperoleh dari Norwegia. Pemungutan jenis pajak ini akan menjadi akan menjadi sisa pekerjaan rumah kembali bagi pemerintah Norwegia (Valkonen and Vihriala, 2014).

Selain penurunan tarif pajak badan, penurunan tarif pajak orang pribadi juga menjadi salah satu agenda. Pilihan kebijakan ini bertujuan untuk mendorong peningkatan produktivitas dan saving, meskipun untuk tarif pajak orang pribadi masih menggunakan konsep tarif progresif dengan empat ketegori, yaitu untuk menggantikan jenis pungutan surtax, social security serta berbagai pungutan lainnya diluar ordinary income tax (Azeman \& Dharmapala, 2018). Selain meringankan beban pajak orang pribadi, sistem pajak pasca reformasi ini juga dianggap lebih memudahkan pemerintah dalam hal pengawasan serta meminimalisir potensi tax planning oleh orang pribadi.

Profit shifting merupakan salah satu permasalahan pajak yang cukup penting bagi Norwegia. Pada umumnya praktik ini dilaksanakan melalu berbagai skema transfer pricing. Meskipun pemerintah telah menyiapkan berbagai aturan, seperti anti avoidance rule, namun proses pemeriksaan terhadap kebenaran pembentukan harga bukanlah perkara yang mudah. Penurunan tarif pajak merupakan salah satu cara untuk meminimalisir hal tersebut, meskipun tidak sepenuhnya dapat mengatasi permasalahan profit shifting selain melalui bentuk pengenaan pajak dengan sistem withholding. Selain itu, Tax Comission juga menekankan konsistensi pelaksaan residence principle dalam sistem perpajakan Norwegia.

Beberapa aspek lainnya yang menjadi perhatian adalah perlakuan atas depresiasi, dimana pemerintah memberikan keringanan kepada industri padat modal. Instrumen yang diberikan adalah adanya tarif tertentu pada tahap awal kegiatan industri dilakukan. Selain itu, sektor finansial juga mendapat perhatian khusus, yaitu diberikan pengecualian atas pemungutan PPN. Meskipun pada akhirnya kebijakan ini menimbulkan permasalahan baru terkait terjadinya distorsi dan pelanggaran prinsip netralitas pemungutan PPN. Selanjutnya, pemungutan PPN dikembalikan sesuai dengan prinsip-prinsip PPN yang berlaku umum sekaligus dengan melakukan improvement dalam hal pengadministrasian dengan memperhatikan prinsip kemudahan dengan pembedaan jenis tarif atas barangbarang tertentu (IMF, 2017).

\section{METODE PENELITIAN}

Penelitian ini menggunakan pendekatan kualitatif. Dalam pendekatan kualitatif, peneliti melakukan kegiatan penelitian yang ditujukan untuk memahami secara mendalam dan berorientasi pada gejala-gejala yang bersifat alamiah. Dengan demikian, karena orientasi dan karakteristiknya demikian, maka sifatnya naturalistik dan mendasar serta tidak dapat dilakukan di laboratorium konvensional, melainkan harus melihat fenomena secara langsung (Creswell, 2003). Salah satu karakteristik penelitian dengan pendekatan kualitatif adalah tidak bebas nilai, dengan artian dalam proses penelitian dapat dipengaruhi oleh berbagai nilai dan pendapatan subjektif. Lebih lanjut, teori yang digunakan dalam pendekatan ini bukan menjadi hal yang sentral, melainkan hanya sebagai dasar kerangka pemikiran untuk melakukan proses analisa data-data berdasarkan temuan di lapangan. Dengan demikian, teori tidak menjadi bahan verifikasi karena hanya bersifat penunjang dalam proses analisis. Pengumpulan data dalam proses penelitian adalah studi literatur dan studi dokumentasi.

\section{DISKUSI DAN HASIL PENELITIAN}

\subsection{Review atas Sistem Perpajakan di Norwegia}

Pembangunan sistem perpajakan, terutama kapasitas administrasi pajak merupakan suatu pekerjaan intelektual jangka panjang yang berdampak pada proses pembangunan ekonomi melalui kebijakan anggaran, yaitu penerimaan pajak. Kapasitas pemajakan disuatu negara dipengaruhi oleh institusi konstitutif, iklim politik yang inclusif dan kondusif serta 
kepemimpinan yang kredibel (IMF, 2015). Kapasitas pemerintahan dipengaruhi oleh interaksi antar variabel berupa kapasitas administrasi pajak, kapasitas hukum dan administrator publik. Dalam proses reformasi yang dilakukan Norwegia berawal pada tahun 1992, aspek improvement dalam hal kebijakan pajak yang menyesuaikan dengan dinamika kegiatan ekonomi global, yaitu semakin borderlessnya suatu negara, dimana mengakibatkan aliran modal semakin mobile telah diupayakan untuk dicarikan jalan keluar. Namun, disisi lain, baik pemerintah maupun Tax Comission menyadari sepenuhnya bahwa kapasitas administrasi pajak yang ditopang dengan penggunaan teknologi yang memadai juga tidak kalah penting. Beberapa bagian yang perlu diulas lebih lanjut mengenai aspek kebijakan pajak dan aspek administrasi pajak yang merupakan unsur pembangun dari sistem perpajakan sehubungan dengan reformasi perpajakan di Norwegia sebagai berikut.

\subsection{Suatu Catatan Dan Review Aspek Kebijakan Pajak}

Dengan adanya pilihan kebijakan penurunan tarif yang mengakibatkan tax potential loss, perlu digali dan diperluas basis pemajakan lainnya untuk mengganti penerimaan akibat potential loss tersebut, perlakuan atas ekuitas dan utang untuk tujuan permodalan (Allowance for Corporate Equity/ACE), permasalahan terkait profit shifting dan transfer pricing. Pada dasarnya, Norwegia menyadari sepenuhnya atas tren perubahan penurunan tarif pajak di Eropa. Hal itu terlihat dengan dibentuknya Tax Comission oleh pemerintah yang bertugas sebagai think thank dan motor penggerak reformasi pajak di Norwegia, dimana tujuan akhir dari reformasi tersebut adalah mendorong aliran modal yang nantinya dapat diharapkan menjadi motor peningkatan produktivitas.

Untuk dapat mengulas mengenai stage reformasi pajak di Norwegia terkini, perlu memahami dengan baik perpajalanan reformasi Norwegia, beberapa garis besar yang perlu diuraikan sebagai berikut. Sebelum reformasi pajak 1992, pemerintah Norwegia menyadari bahwa tarif statutori atas kapital dan tenaga kerja cukup tinggi. Selain itu, terdapat cukup banyak jenis biaya pengurang dan fasilitas insentif pajak atas pembelian aset. Hal ini diyakini menyebabkan besarnya volume investasi yang sebenarnya tidak profitable bagi pemerintah Norwegia. Keadaan yang demikian, yaitu besarnya unnecessary tax expenditure merupakan faktor penting terbentuknya Tax Comission sebagai suatu badan yang bertugas untuk melakukan review terhadap sistem perpajakan Norwegia, serta mengambil langkah-langkah yang perlu dalam agenda reformasi pajak. Pada masa awal reformasi, Tax Comission mengusulkan tax cut, penataan aturan mengenai akumulasi utang atas modal yang menjadi pengurang beban pajak, pemajakan atas payroll (payroll tax) serta pemungutan social security atas labor income, tidak atas capital income, ketentuan penyusutan berdasarkan nilai ekonomi ril. Konsep dari pemajakan penghasilan pasca reformasi dikenal sebagai dual income, yaitu adanya tax on capital dan tax on labor income. Dampak dari struktur pajak pra reformasi adalah rendahnya saving, rendahnya return on investment, rendahnya investasi dan tingginya distorsi (Riskjell, 2014).

Dalam menjalankan agenda reformasinya, jika dibandingkan dengan trend penurunan tarif anggota OECD, hingga tahun 2005, tarif pajak efektif rata-rata Norwegia lebih rendah dari tarif rata-rata anggota OECD, kemudian ditahun berikutnya hingga saat ini, tarif pajak rata-rata efektif Norwegia lebih tinggi sekitar $2 \%$ dari rata-rata anggota OECD lainnya. Norwegia masih mengenakan pajak atas kekayaan bersih (net wealth tax) sebesar 1,1\% pada threshold terendah. Berdasarkan review yang dilakukan oleh OECD, pilihan kebijakan pajak yang demikian tidak termasuk dalam praktik harmful tax competition, melainkan defensive tax competition. Hal ini didasarkan bahwa tujuan dari penurunan tarif pajak korporasi adalah untuk mencegah emigrasi cabang-cabang tertentu dari entitas bisnis ke jurisdiksi lain, bukan offensive tax competition yang memang diarahkan untuk menarik entitas bisnis baru ke Norwegia dari jurisdiksi lainnya (Onstand-Gjems,2012). Adapun justifikasi bahwa penurunan tarif pajak tersebut tidak merupakan praktik tax competition adalah sebagai berikut (Onstand-Gjems, 2012, 4).

a. tarif pajak yang tidak terlalu tinggi juga diberikan kepada investor domestik dimana atas keuntungan entitas bisnisnya didistribusikan. Selain itu, berbagai pola dan skema tax incentives juga tidak masif yang ditujukan semata-mata untuk menarik investor. Selain itu, tarif withholding tax (20\%) tidak cukup rendah untuk dikategorikan sebagai penurunan tarif yang agresif.

b. ketentuan akuntansi berlaku secara umum, tidak terdapat perlakuan akuntansi yang berbeda bagi investor asing seperti tax defferal atau tax free-roll over

c. Norwegia mempunya 80 perjanjian penghindaran pajak berganda dan dengan ketentuan transfer pricing sesuai rekomendasi dalam OECD Transfer Pricing Guidelines. Selain itu, Norwegia berkomitmen dalam melaksanakan exchange of information ketika telah menandatangani perjanjian penghindaran pajak berganda.

d. Norwegia melaksanakan advance ruling serta tidak terdapat perlakuan khusus dalam advance ruling tersebut dan berbagai komitmen internasional lainnya.

Namun, disisi lain pilihan kebijakan pajak yang dilakukan pemerintah Norwegia dalam kerangka reformasi pajaknya perlu diberikan catatan. Dapat 
ditekankan bahwa, cukup sering terjadi reformasi perpajakan justru menyebabkan distorsi karena pilihan kebijakan yang bersifat non-netral. Hal ini juga menjadi permasalahan bagi pemerintah Norwegia. Pada dasarnya, ketika terjadi distorsi akibat implementasi kebijakan pajak, maka akan melanggar prinsip social efficiency karena harga yang sebenarnya tidak identik dengan biaya yang sebenarnya (Schejelderup, 2012). Christiansen (2006) menyebutkan bahwa distorsi akibat kebijakan pajak yang sering muncul disebabkan oleh hal-hal berikut, dimana permasalahan inipun masih menjadi bagian dari agenda reformasi di Norwegia:

a. bunga akibat pinjaman untuk pembiayaan merupakan pengurang pajak, sementara modal sebagai sarana pembiayaan bukan pengurang pajak, artinya terjadi diskriminasi antara debtfinancing dan equity-financing. Resiko yang mungkin terjadi adalah tingginya tingkat utang sehingga berdampak pada solvency serta rendahnya equity-financing. Struktur permodalan semakin tidak optimal yang pada akhirnya berdampak pada kesejahteraan.

b. depresiasi pajak yang tidak sesuai dengan depresiasi biaya yang sebenarnya. Pembebanan penyusutan yang sangat besar sehingga menurunkan beban pajak mengakibatkan bias dimana perusahaan menggunakan aset yang nilai pembukuannya tidak sesuai dengan nilai rilnya

c. ketidakpastian terkait perhitungan inflasi. Inflasi mempengaruhi efisiensi pemajakan atas korporasi dalam 2 hal, yaitu bunga nominal merupakan pengurang, sementara selisih antara bunga nominal dan bunga ril bukan pengurang, selanjutnya depresiasi dihitung berdasarkan nilai nominal, bukan berdasarkan nilai penggantian.

Pada kenyataannya, mengutip penelitian empiris yang dilakukan oleh Riskjell (2014), korporasi di Norwegia cenderung memilih debt to equity karena sistem perpajakannya memungkinkan untuk dilaksanakan praktik tersebut, sehingga sistem perpajakan belum dianggap netral. Ketika volume investasi meningkat, justru terjadi penurunan profitabilitas serta rate of return menurun ketika capital stock meningkat. Selain itu, terkait dengan treatment atas depresiasi yang berbeda-beda, penelitian empiris menunjukkan bahwa sangat sulit untuk menghitung penyesunan yang nyata secara ekonomis. Untuk kemudahan administrasi, pemerintah Norwegia mengklasifikasikan aset kedalam beberapa kelompok. Sebagai dampaknya, aset dengan kelas yang sama, tarif penyusutan dapat menjadi lebih rendah atau lebih tinggi, yang artinya akan terjadi underinvestment atau over-investment atas investasi yang dalam satu kelas.
Terkait dengan praktik profit shifting, penelitian empiris (Riskjell, 2014) menemukan bahwa ketika tarif pajak efektif di Norwegia lebih tinggi dari tarif pajak negara tetangga, terdapat kecenderungan pengalihan laba melalui transfer pricing. Perilaku ini merupakan tekanan bagi sistem perpajakan Norwegia untuk menurunkan tarif pajaknya. Pilihan kebijakan berupa ACE yang digagas sejak tahun 1991 merupakan alternatif untuk mengurangi distorsi dan menggiring sistem perpajakan lebih netral dalam hal perlakuan antara utang dan modal dalam pembiayaan serta koreksi terhadap perhitungan penyusutan.

Jika memperhatikan negara anggota OECD lainnya yang menerapkan kebijakan sejenis ACE, misalnya Belgia pada tahun 2006. Belgia menerapkan system of the "notional interest deduction". Sistem ini memperkenalkan equity tax shield artinya perlakukan pengurangan yang sama atas cost of equity dan cost of debt. Penelitian empiris (Princen, 2012) menunjukkan bahwa pola praktik pembiayaan konsisten dengan teori, artinya perlakuan pajak yang sama atas debtfinancing dan equity-financing mampu menurunkan tingkat utang perusahaan. Selain itu, Italia pada tahun 2011, memperkenalkan konsep Aiuto Alla Crescita Economia, suatu instrumen untuk menstimulus kapitalisasi atas korporasi. Adanya instrumen demikian menurunkan pola pembiayaan dengan hutang, yang pada akhirnya mampu meningkatkan laba bersih.

Terkait penarikan pajak atas kekayaan bersih (net wealth tax) yang dilaksanakan oleh beberapa negara OECD masih terus dalam perdebatan. Kritik yang sering terlontar adalah dampak negatifnya atas performa ekonomi. Meskipun disisi lain teradapat argument yang mengatakan penarikan wealth tax tidak membebani entitas bisnis investor sebagai pihak yang tidak dikenakan jenis pajak ini, sehingga justru dapat disebut sebagai bentuk lain dari insentif karena tidak berdampak pada aliran modal. Pada dekade terakhir, beberapa negara anggota OECD seperti Denmark dan Swedia memutuskan untuk tidak memungut jenis pajak ini. Hal yang cukup berbeda dengan Norwegia yang masih menerapkan pemungutan jenis wealth tax (Hansson, 2010). Namun, pemungutan pajak di berbagai negara lainnya, tetangga Norwegia tersebut oleh Hannson (2010) menyebutkan bahwa pilihan kebijakan tersebut tidak terlepas dari aspek politis pemerintah, terutama terkait pertimbangan ideologi partai yang sedang menjabat dalam pemerintahan dan sedang menjalankan pemerintahan.

Disisi lain, sejumlah scholar dari negara yang tidak memungut wealth tax seperti Amerika Serikat, Australia dan Afrika Selatan justru menyarankan untuk tetap memungut wealth tax dengan tujuan pemerataan kesejahteraan dan meningkatkan kapasitas demokrasi sebagai legitimasi pemungutan. Hansson menyebutkan bahwa sejatinya belum terdapat penelitian yang secara statistik cukup memadai dengan signifikansi yang tinggi yang 
menjelaskan hubungan antara wealth tax dan pertumbuhan ekonomi, sebagai suatu dimensi penting yang melegitimasi pemungutannya. Bahkan, Hansson melakukan penelitian terhadap hubungan kedua variabel tersebut terhadap 20 negara anggota OECD dalam kurun waktu 1980-1999 dan menyimpulkan bahwa hubungan/korelasi antara keduanya sangat lemah, yaitu pada angka 0.02 dan 0.05 persen.

Pelaka (2013) mengemukakan perspektif yang berbeda mengenai pemungutan wealth tax di Norwegia. Pelaka (2013) membangun sebuah model untuk melakukan prediksi dan proyeksi penerimaan di masa mendatang serta efek distribusi dari wealth tax dan inherintance tax di Norwegia dalam kurun waktu 2010-2040. Berdasarkan model tersebut, diprediksi bahwa wealth tax tersebut akan memberikan kontribusi yang signifikan bagi penerimaan negara dalam kurun waktu pemodelan. Selain itu, ketimpangan kemakmuran juga semakin menurun yang ditandai dengan penurunan rasio gini, yang memungkinkan untuk memberikan efek jangka panjang. Jika pemerintah Norwegia menghapuskan net wealth tax, maka kelompok individu yang tergolong wealth taxpayer akan memperoleh manfaat yang signifikan dari pengurangan beban pajaknya. Namun, Pelaka kembali memberikan disclaimer bahwa terdapat aspek politik dalam tataran nasional dan internasional yang kerap mempangaruhi pilihan kebijakan terkait wealth tax.

Namun, dengan temuan penelitian yang demikian, terdapat sejumlah argument yang menyebutkan bahwa pemungutan wealth tax berdampak negatif terhadap pertumbuhan, bahkan dikategorikan sebagai harmful taxes karena dianggap mempengaruhi keputusan investasi dari pemilik modal sehingga akan mempengaruhi pertumbuhan ekonomi (Tanzi, 1995). Memang benar bahwa wealth tax akan mempengaruhi net return, namun apakah net return yang lebih rendah secara kuat berkorelasi terhadap saving dan bagaimana saving tersebut berpengaruh terhadap investasi belum cukup jelas penyimpulannya.

Terlepas dari pertimbangan politik pemerintah dalam memungut wealth tax, menyitir pendapat Atkinson dan Stiglitz (1980) mengenai pemungutan wealth tax yang sepertinya sudah cukup klasik dan kemudian direfleksikan dengan proses perjalanan reformasi yang tengah dilaksanakan oleh pemerintah Norwegia, maka pendapat tersebut masih cukup relevan. Atkinson dan Stiglitz (1980) mengatakan bahwa ketika tidak terdapat konsensus yang cukup kuat untuk memungut wealth tax, maka pemungutan pajak wealth tax sebenarnya tidak terlalu beresiko dibandingkan pemungutan pajak atas kapital meskipun keduanya sama-sama mengurangi net return. Namun, Atkinson dan Stiglitz menekankan bahwa pemungutan wealth tax hanya mendatangkan penerimaan dalam jumlah yang kecil daripada pajak atas kapital, sementara dampak dari asumsi yang timbul dari pemungutan jenis pajak ini adalah semakin besarnya resiko beban pajak yang dihadapi investor ketika menanamkan modalnya. Tentu hal ini akan menimbulkan friksi baru. Perlu juga dikemukakan bahwa, bagi Norwegia yang memiliki pendapatan perkapita cukup tinggi dibandingkan negara anggota OECD lainnya, dengan koefisien gini yang cukup stabil sejak tahun 2008, pemungutan pajak wealth tax mungkin bukan hal yang cukup krusial dan siginifikan, berbeda dengan negara berkembang dan industrialisasi dimana masalah kesenjangan masih cukup tinggi, sehingga diperlukan pemerataan pertumbuhan ekonomi.

Selanjutnya, terkait penurunan beban pajak yang disertai dengan pengalihan beban pemungutan pajak dari pajak langsung menjadi pajak tidak langsung diharapkan mampu meningkatkan produktivitas. Pergeseran sumber penerimaan tersebut diikuti dengan penaikan tarif pajak atas konsumsi (OECD, 2017). Pajak atas konsumsi di Norwegia tergolong tinggi. Bahkan tarif umum PPN mencapai $25 \%$, lebih tinggi dari rata-rata anggota OECD namun sama dengan Denmark dan Swedia. Terdapat beberapa jenis penyerahan barang/jasa tertentu dengan tarif rendah yaitu $0 \%, 10 \%$ dan $15 \%$ yang telah ditentukan sejak 2005. Sebagai hasilnya, VAT Revenue Ratio (VRR) Norwegia mencapai 0,56 pada tahun 2014 (OECD, 2016). Hal ini menggambarkan bahwa pergeresan penerimaan dari pemajakan atas kapital menjadi pemajakan atas konsumsi tergolong berhasil.

\subsubsection{Aspek Administrasi Pajak}

Dalam artikel diatas terkait bagian reformasi pajak mengenai optimalisasi administrasi perpajakan, disebutkan bahwa penggunaan teknologi menjadi sarana penting dalam pengimplementasiaannya. Hal tersebut semakin urgent ketika diharapkan pada kegiatan pengawasan kepatuhan wajib pajak. OECD (2016) menyebutkan bahwa penggunaan teknologi dengan memanfaatkan big data serta interkoneksi antara otoritas pajak dengan wajib pajak merupakan suatu langkah maju sebagai sarana dalam melaksanakan administrasi perpajakan yang mudah sekaligus sebagai sarana dalam meningkatkan pengawasan terhadap kepatuhan seperti mampu mencegah penggelapan pajak, meningkatkan jumlah wajib pajak, misalnya pelaku usaha kecil (UMKM). Secara khusus, terkait aspek wajib pajak UMKM, penggunaan teknologi yang terhubung dengan pelaku usaha tersebut, akan menjadikan UMKM dari marketdriven menjadi government-driven. Dengan memaksimalkan penggunaan teknologi dalam menjalankan administrasi perpajakan, juga akan mendorong timbulnya ide-ide baru dalam mengoptimalkan kegiatan tersebut menyesuaikan dengan perubahan lingkungan yang demikian cepat. 
Secara spesifik, OECD (2016) menggarisbawahi beberapa hal berikut terkait penggunaan teknologi dalam mengoptimalkan pelaksanaan administrasi pajak termasuk berbagai potensi tantangan yang dihadapi. Pada kondisi lain, hadirnya teknologi juga turut serta mendorong lahirnya berbagai jenis produk, layanan dan model bisnis baru, yang menjadi tambahan tantangan baru bagi administrator pajak. Dengan demikian, pembahasan ini juga kemungkinan relevan dalam konteks administrasi perpajakan di Norwegia meskipun tergolong sebagai negara yang memiliki kepatuhan perpajakan yang cukup baik.

a. Era disruptive technology mempengaruhi pola kegiatan ekonomi secara signifikan. Hal ini berarti administrator pajak tidak akan lebih mudah untuk memungut pajak karena harus disertai dengan pemahaman yang baik mengenai pola kegiatan bisnis atas suatu entitas. Disisi lain, otoritas pajak juga diharapkan mampu mengimbangi pola bisnis entitas tersebut untuk memberikan layanan berbasis teknologi (digital-by-default). Bagi entitas usaha, masih adanya kewajiban pajak dengan otoritas pajak yang tidak dapat mengimbangi kemajuan entitas bisnis, merupakan suatu bentuk inefisiensi apabila harus mengeluarkan sumber daya untuk memenuhi kewajiban perpajakan semata. Tantangan yang dihadapi oleh otoritas pajak seperti (i) harus tersedianya informasi yang memadai dan cukup jelas mengenai kewajiban pajak dari wajib pajak secara real-time, termasuk konsultasi online, serta pengisian SPT berbasis teknologi (ii) mengupayakan adanya pembayaran pajak berbasis online yang dilengkapi dengan konfirmasi pembayaran online serta tersedianya form atau kalkulator penghitungan beban pajak secara online. Dengan demikian, otoritas pajak dihadapkan pada tantangan dimana wajib pajak ditempatkan sebagai pelanggan dan diharapkan mampu meningkatkan kepuasan wajib pajak atas layanan yang diberikan, termasuk mengenai transparansi.

b. Penggunaan big data untuk mengetahui kegiatan entitas bisnis dan mengawasi perilaku bisnisnya untuk membuat berbagai jenis prediksi dan simulasi. Big data juga menjadi sumber untuk melakukan profiling dalam rangka manajemen risiko. Dengan demikian, hal ini memaksa petugas pajak untuk selalu meningkatkan kapabilitasnya yang pada akhirnya melahirkan budaya organisasi baru, yaitu data-driven culture dalam merumuskan strategi dan kebijakan. Tentu, pada akhirnya perubahan pola kegiatan tersebut akan mempengaruhi struktur organisasi otoritas pajak. c. Pemberian layanan perpajakan dengan menggunakan digital services seperti dalam hal pengisian SPT, pembayaran online beserta konfirmasinya, tracking restitusi dan berbagai layanan lainnya dengan keamanan penyimpanan informasi yang terpercaya serta akurat. Pelaksanaan sistem administrasi yang demikian membutuhkan partisipasi proaktif dari petugas pajak.

OECD (2015) mempublikasikan bahwa tren administrasi saat ini bahwa otoritas pajak bertugas tidak semata-mata sebagai lembaga pemungut pajak, melainkan sebagai instansi yang memberikan layanan kepada masyarakat. Konsep ini merupakan pendekatan baru sebagai suatu inovasi dalam era modern dalam proses pendidikan pajak bagi masyarakat, sehingga pada akhirnya dapat meningkatkan kepatuhan. Kepatuhan yang diharapkan berada pada level cooperative compliance dimana wajib pajak memiliki keinginan dan kemampuan untuk melakukan disclosure atas informasi perpajakan yang dimiliki secara transparan. Informasi yang dikemukakan tersebut merupakan informasi yang benar, terpercaya dan valid yang pada akhirnya menjadi dasar penghitungan besar beban pajak yang harus disetorkan ke kas negara (OECD, 2016).

Dalam proses reformasi sistem perpajakan yang semakin modern di Norwegia tidak terlepas dari peran penting pemerintah yang memiliki kapasitas institusional yang baik melalui komite (Tax Comission) yang didekasikan untuk menyusun, menjalankan dan mengawasi agenda reformasi pajak, dimulai sejak 1984. Pembentukan Tax Comission didasari pada suatu visi dan target yang jelas, yaitu membangun sistem perpajakan yang didasarkan pada prinsip efisiensi untuk mendatangkan aliran modal (efficiency allocation of capital) serta minimalisasi distorsi (Christiansen, 2004). Selain memiliki kewenangan yang cukup, konsistensi bekerja dari Tax Comission menjadi perpaduan yang baik dalam proses reformasi yang terus menerus dijalankan.

Dalam teknis pengadministrasian, Norwegia tergolong lebih maju dari negara welfare state tetangganya. Otoritas pajak membangun suatu sistem dengan kode-kode tertentu yang secara administratif cukup unik ketika mengenakan pajak kepada wajib pajaknya, yang disebut RISK. Otoritas pajak memiliki fungsi memastikan dan memanajemen bahwa pajak telah dibayarkan dengan tepat dengan perhitungan yang benar sekaligus melakukan manajemen atas data base wajib pajak secara real-time. Peran administrasi pajak yang cukup besar dalam kegiatan pemerintahan Norwegia sangat disadari dan dirasakan oleh masyarakat, terutama ketika otoritas pajak mampu menghimpun hingga lebih dari $80 \%$ penduduk sebagai bagian dari sistem perpajakan nasional (MoF, 2014). 


\subsection{Catatan atas Reformasi Perpajakan Indonesia}

Pada dasarnya, keberadaan Norwegia dan Indonesia merupakan dua negara dengan karakteristik ekonomi yang sangat berbeda. Namun, keberhasilan Norwegia dalam menjalankan reformasi perpajakannya dapat menjadi refleksi bagi Indonesia yang kini masih terus berupaya menjalankan agenda reformasinya. Indonesia telah memulai reformasi perpajakan sejak 1981, dimana ketika saat itu terjadi perubahan mendasar baik terkait pembentukan UU baru, perubahan sistem pemungutan pajak (dari official assessment menjadi self-assessment), adanya perombakan struktur organisasi, modernisasi sistem pelayanan bagi wajib pajak. Adapun perubahan mendasar tersebut karena pemerintah Indonesia mulai menyadai bahwa pemerimaan negara tidak dapat lagi bergantung pada Sumber Daya Alam dan Migas (Gitte Heij, 1993) dan negara memerlukan sumber penerimaan yang berkesinambungan.

Setelah berjalannya reformasi perpajakan, namun pada kenyataannya, tax ratio Indonesia tertutama terhitung sejak 10 tahun terakhir masih cukup rendah dibandingkan negara tetangga di ASEAN seperti Malaysia (15\%), Vietnam (16\%), Thailand (10\%) (ADB, 2018). Hal tersebut disebabkan oleh tingkat kepatuhan yang masih tergolong rendah dan besarnya berbagai fasilitas perpajakan berupa tax incentives dengan berbagai bentuk kemudahan lainnya (Iswahyudi, 2017, 87) dengan kisaran angka tax ratio sebesar rata-rata $12 \%$. Jika penerimaan pajak dijumlahkan dengan pungutan-pungutan lainnya, maka total penerimaan tersebut berada di kisaran 14\% (Christine Lewis). Indonesia dalam proses reformasi perpajakannya terus berupaya untuk meningkatkan persentase tax-to-GDP ratio setidaknya $2 \%$ dari tahun sebelumnya (Christine Lewis, 2019). Selama proses perjalanan reformasi, setidaknya terdapat dua fase besar yang cukup substantial dalam proses bertransformasi (Fuad Bawazier, 2011; Prasetyo, 2018). Berikut akan diuraikan fase reformasi perpajakan di Indonesia baik dalam aspek kebijakan maupun aspek administrasi.

\subsubsection{Suatu Catatan Dan Review Aspek Kebijakan Pajak}

Pada fase awal reformasi perpajakan di Indonesia, diperkenalkannya UU Pajak Penghasilan merupakan langkah besar dalam reformasi perpajakan. UU Pajak Penghasilan ini menggantikan 3 UU perpajakan yang mengatur sehubungan dengan pemajakan atas penghasilan yaitu UU terkait Penghasilan Korporasi, Penghasilan Individu dan Penghasilan dari Bunga, Dividend dan Royalti (Eureka Putra, 2014, 56). Ketika ketentuan baru diperkenalkan, diterbitkan pula kebijakan penurunan tarif korporasi dan individu dimana sebelumnya tarif korporasi sebesar $45 \%$ dan individu maksimum $50 \%$ menjadi maksimum $35 \%$ bagi keduanya. Selain itu, diperkenalkan juga UU Pajak Pertambahan Nilai (PPN) mengganti sales tax dan turnover tax dengan tarif $10 \%$. Sistem PPN yang diperkenalkan telah mengikuti sistem PPN yang lazim (Gitte Heij, 1993).

Pada fase kedua, ketika Indonesia turut serta mengalami krisis ekonomi, perubahan signifikan juga terjadi bagi sistem perpajakan. Penurunan tarif pajak bagi korporasi juga dilakukan yang sebelumnya berada pada maksimum kisaran 35\% menjadi 30\% di tahun 1994, kemudian menjadi $28 \%$ di tahun 2008 dan $25 \%$ di tahun 2010. Tarif korporasi $28 \%$ dan $25 \%$ tersebut bersifat flat. Hal ini ditujukan untuk menawarkan suatu iklim yang ramah bagi investasi sekaligus untuk mempermudah perhitungan kewajiban pajak bagi wajib pajak korporasi (Eureka Putra, 2014). Selain itu, beberapa perubahan penting lainnya seperti perubahan terkait penghasilan yang dikenakan pajak dan subyek pajak penghasilan.

Adapun hal substansial yang menjadi perhatian pada fase kedua, misalnya, pada tahun 1994, agar dapat mengenakan pajak atas penghasilan yang tidak seluruhnya dilaporakan dalam SPT, dilakukan perluasan basis pemajakan yaitu memperkenalkan ketentuan baru yang memungkinkan untuk memajaki setiap kenaikan kekayaan wajib pajak dari pendapatan yang tidak dilaporkan. Kemudian, pada tahun 2000, penghasilan berupa inter-company dividen menjadi dikenakan pajak. Selanjutnya, pada 2008, atas surplus yang diterima oleh Bank Indonesia dikategorikan sebagai Penghasilan Kena Pajak. Oleh karena itu, dari uraian tersebut, dapat dilihat bahwa Indonesia telah mengadopsi pendekatan perluasan basis (broading tax base) dengan menerapkan kebijakan pemotongan tarif pajak. Pendekatan ini sangat populer di banyak negara karena pendekatan ini diyakini tidak hanya akan meningkatkan pendapatan pajak tetapi juga meningkatkan kepatuhan pajak, kemudahan administrasi, kesetaraan, dan efisiensi (Putra, 2014).

Perubahan pajak berikutnya adalah terkait kebijakan insentif pajak. Kebijakan perpajakan Indonesia tentang insentif pajak telah berubah dari kebijakan menentang insentif pajak ke kebijakan yang mendukung insentif pajak. Pada reformasi pajak penghasilan tahun 1983, pembuat kebijakan memilih untuk menjunjung tinggi prinsip keadilan sistem perpajakan daripada memberikan insentif pajak untuk kelompok pembayar pajak tertentu yang mungkin menciptakan ketidakadilan terhadap sistem perpajakan. Namun, mulai tahun 1994, pembuat kebijakan memilih posisi yang berlawanan dengan memberikan insentif pajak bagi wajib pajak tertentu untuk mendorong dan mempercepat investasi terutama daerah terpencil.

Saat ini, justru kebijakan insentif sangat gencar untuk mendorong investasi. Pada tahun 2018, pemerintah mengeluarkan Peraturan Pemerintah 
melalui Peraturan Menteri Keuangan No.35/PMK.010/2018 yang memberikan fasilitas tax holiday bagi investor (Kemenkeu, 2018). Terlebih lagi, pada tahun 2019, pemerintah juga kembali mengeluarkan insentif pajak (PP No.45/2019) bagi industri tertentu dan industri pionir. Dengan demikian gencarnya pemberian insentif justru dikhawatirkan hal tersebut justru tidak cukup efektif untuk menarik investor serta dapat menggerus basis pemajakan. OECD (2019) berpendapat justru terkait investment attraction, insentif bukanlah faktor penting, melainkan hal lain seperti kemudahan administrasi dan kepastian hukum. Dalam konteks perpajakan internasional, Indonesia telah meratifikasi hingga 60 perjanjian pajak. Jumlah ini dapat dikategorikan sebagai jumlah besar untuk negara berkembang. Sebagian besar perjanjian ini akan bermanfaat bagi negara-negara maju yang merupakan negara sumber investor (DDTC, 2015). Fenomena ini mendorong Base Erosion Profit Shifting (BEPS) dan potensi penghindaran pajak lainnya melalui berbagai skema jika pemerintah belum mengambil langkah yang lebih konkrit (Gunadi, 2014; DDTC, 2015).

Badan Kebijakan Fiskal menyampaikan posisi pemerintah tentang masalah penghindaran dan Base Erosion and Profit Shifting yang berdampak negatif pada potensi penerimaan pajak Indonesia dan kepercayaan publik terhadap sistem perpajakan. Posisi pemerintah normatif terkait dengan erosi dasar di setiap pertemuan G20 (Kantor Kebijakan Fiskal, 2014:

a. Indonesia mendukung agenda BEPS dan agenda pertukaran informasi untuk meningkatkan sistem perpajakan global terintegrasi

b. Indonesia berencana untuk mengimplementasikan BEPS secara komprehensif dan khusus untuk negara yang berfokus pada pencegahan penyalahgunaan perjanjian pajak

c. Meningkatkan kapasitas administrasi perpajakan sebagai Lembaga yang bertugas untuk memungut pajak

d. d. Mengadopsi secara voluntary konsensus global compatible dengan ketentuan perpajakan domestik

Di sisi lain, penelitian yang dilakukan oleh Rahayu (2010) bertujuan untuk mengidentifikasi praktik kecenderungan penghindaran pajak yang dilakukan oleh perusahaan multi nasional (MNC) di mana pemerintah menawarkan insentif pajak untuk meningkatkan realisasi investasi langsung dari modal yang berasal dari luar negeri Foreign Direct Investment. Fakta menunjukkan bahwa selama penelitian berlangsung (2010) ditemukan bahwa hingga $70 \%$ dari perusahaan multinasional tersebut belum memenuhi kewajiban pajaknya dengan benar atau bahkan menyampaikan Surat Pemberitahuan Pajak Penghasilan yang menunjukkan bahwa perusahaan tersebut kerugian besar untuk jangka waktu yang lama yang berlangsung secara konsekutif. Dengan demikian, kedepannya perlu diambil suatu langkah kebijakan yang lebih tepat dengan melakukan evaluasi terhadap kebijakan yang pernah dilakukans serta mempertimbangkan kembali kebijakan serupa yang pernah dilakukan di negara lain yang ditujukan untuk meminimalisir penghindaran pajak.

\subsubsection{Aspek Administrasi Pajak}

Pada awal reformasi perpajakan, langkah awal yang dilakukan pemerintah terkait pembangunan sistem administrasi adalah memperkenalkan sistem pemungutan pajak yang dulunya official assessment (petugas pajak menetapkan besar pajak terutang) menjadi self-assessment (besaran pajak ditentukan oleh wajib pajak). Untuk melaksanakan proses selfassessment sistem pendaftaran Nomor Pokok Wajib Pajak (NPWP) pun diperkenalkan. Adanya NPWP tersebut menjadi sarana administrasi bagi wajib pajak untuk berperan aktif menjalankan kewajiban perpajakannya. Dalam ketentuan UU Ketentuan Umum dan Tata Cara Perpajakan Indonesia dengan amandemen terakhir tahun 2007 pada Pasal 12 memberikan kepercayaan bagi wajib pajak bahwa Surat Pemberitahuan (SPT) yang berisi pelaksanaan kewajiban perpajakan telah dilaksanakan dengan benar.

Pada fase kedua reformasi, pemerintah Indonesia melalui Direktorat Jenderal Pajak (DJP) mulai melakukan segmentasi Kantor Pelayanan Pajak (KPP) sesuai dengan karakteristik wajib pajaknya. Hal ini salah satu bentuk perubahan paradigma dimana administrasi perpajakan akan lebih berorientasi kepada pelayanan, misalnya dengan dibentuknya Large Taxpayer Officer (LTO), sehingga memudahkan pelayanan baik bagi wajib pajak maupun bagi petugas pajak (LTO) (Ikhsan, 2005). Selain itu, hal ini juga lebih mempermudah petugas pajak dalam memonitor kepatuhan dari wajib pajak yang tersegmentasi dalam suatu KPP. Pementukan LTO dilakukan pada 2002, kemudian diikuti dengan pembentukan KPP Madya (bagi wajib pajak menengah) dan KKP Pratama (bagi wajib pajak kecil dan orang pribadi) pada 2004. Ketika dilakukan segmentasi tersebut, jumlah wajib pajak meningkat dengan cukup tajam, yang pada akhirnya diharapkan mampu meningkatkan penerimaan negara (Prasetyo, 2018).

Pada tahun 2008, modernisasi sistem administrasi terus dilaksanakan yang ditujukan untuk meningkatkan kepatuhan sukarela (voluntary tax compliance) dan meningkatkan kualitas pelayanan. Adapun upaya yang dilaksanakan dalam mencapai perubahan tersebut meliputi:

a. Perubahan organisasi; administrasi perpajakan diupayakan berfokus pada service-oriented, misalnya dengan menggabungkan KPP, KP PBB dan Karikpa sehingga wajib pajak tidak perlu 
mendatangi beberapa kantor pajak untuk tujuan yang berhubungab.

b. Perubahan proses bisnis; adanya standard operating procedure (SOP) terkait pelayanan dan diperkenalkannya sistem elektronik dalam hal pembuatan NPWP (e-registration), pengisian Surat Pemberitahuan (e-filing) dan hingga kini layanan terus berkembang dengan menggunakan sistem elektronik.

c. Perubahan manajemen Sumber Daya Manusia (SDM); adanya competence assessment dan adanya internalisasi nilai-nilai bahwa administrasi perpajakan Indonesia berorientasi pada pelayanan.

Hingga saat ini, proses modernisasi sistem adminsitrasi pajak tengah diupayakan dengan mengoptimalkan penggunaan teknologi. Diharapkan dengan dioptimalkannya teknologi dan adanya layanan berbasis digital, otoritas pajak dapat meningkatkan layanan sekaligus menghimpun data wajib pajak. Pihak otoritas pajak Indonesia, Direktorat Jenderal Pajak (DJP) juga sudah semakin menyadari bahwa era teknologi saat ini seharusnya dapat dijadikan peluang. Salah satu upaya DJP dalam mengelola compliance risk adalah melalui pengembangan sistem Compliance Risk Management (CRM) berbasis data (kemenkeu.go.id, 2017). Kedepannya, pengembangan sistem CRM ini merupakan salah satu pilar penopang reformasi administrasi perpajakan.

Pada tahun 2016, UU Pengampunan Pajak (tax amnesty) yaitu UU No. 11 tahun 2016 diterbitkan. Dengan hadirnya ketentuan tersebut wajib pajak yang sebelumnya belum melaporkan seluruhnya diberikan kesempatan untuk menyelesaikan kewajibannya dengan sanksi bunga yang cukup rendah. Adapun tujuan dari diterbitkannya UU tersebut adalah selain menghimpun penerimaan pajak, juga untuk memperoleh informasi tambahan terkait potensi keuangan wajib pajak Indonesia. Hal yang sejenis juga pernah dilaksanakan pada tahun 2008 yaitu dengan adanya Sunset Policy berupa penghapusan sanksi administrasi bagi wajib pajak yang menyelesaikan kewajiban perpajakannya ditahun sebelumnya namun belum diselesaikan sesuai ketentuan yang berlaku di masa itu (pajak.go.id, 2008). Diharapkan dari informasi tersebut dapat digunakan untuk memonitor kewajiban wajib pajak.

Setelah sekian dekade reformasi perpajakan Indonesia berjalan, berdasarkan studi yang dilakukan oleh World Bank atas taxing capacity Indonesia dalam kurun waktu 1994-2009, Indonesia masih tergolong sebagai negara dengan kapasitas pemungutan pajak yang rendah. Target pemungutan pajak hanya tercapai pada tahun 2008 ketika program sunset policy dilaksanakan (Minh Le et., al, 2012). Studi terakhir yang dilakukan oleh Asian Development Bank pada 2018 menyebutkan bahwa kapasitas pemajakan Indonesia masih di kisaran rata-rata 12\%. Masih rendahnya tingkat kepatuhan perpajakan masih merupakan tugas besar pemerintah dalam menjalankan administrasi perpajakan. Dalam era modernisasi administrasi, jumlah wajib pajak mengalami peningkatan, namun belum secara signifikan meningkatkan kepatuhan (Christine Lewis, 2019). Dengan demikian, pekerjaan rumat terkait administrasi adalah meningkatkan voluntary compliance.

\subsection{Reformasi Perpajakan di Indonesia: Bercermin dari Reformasi Perpajakan di Norwegia}

Adanya upaya pemerintah Indonesia untuk mencari sumber penerimaan lain dengan tidak mengandalkan sumber daya alam, kemudian beralih ke sektor perpajakan merupakan suatu keniscayaan seperti halnya yang dilakukan oleh Norwegia ketika telah menyadari bahwa penerimaan negara tidak dapat sepenuhnya bergantung pada SDA dan Migas. Sumber penerimaan pajak dianggap sebagai suatu sumber yang berkelanjutan. Disisi lain, bagaimana mempertahankan keberlanjutan tersebut dengan pembentukan sistem perpajakan yang baik merupakan pekerjaan rumah yang akan juga berkelanjutan bagi kedua negara. Rangkaian reformasi perpajakan bukanlah menjalankan suatu rutinitas semata, karena sistem tersebut harus compatible dengan tren perpajakan dunia dan sekaligus compatible dengan kondisi domestik Indonesia.

Bercermin dari reformasi perpajakan di Norwegia, pada awal reformasi perpajakan Indonesia 1983, Indonesia telah berada track yang tepat, yaitu melakukan simplifikasi sistem administrasi perpajakan, penurunan tarif penghasilan dimana sebelumnya tarif pajak baik individu maupun korporasi dinilai terlalu tinggi, diperkenalkannya sistem PPN serta perkenalan withholding tax untuk memudahkan pemungutan pajak. Untuk mendukung agenda reformasi perpajakan, Indonesia juga telah melakukan restrukturisasi organisasi otoritas pajak dengan mengubah value organisasi yang lebih memfokuskan kepada pelayanan kepada wajib pajak (OECD, 2010).

Adanya segmentasi Kantor Pelayanan Pajak sebagai bentuk upaya optimalisasi pelayanan merupakan langkah maju dimana terjadi perubahan paradigma bahwa hubungan antara wajib pajak dan otoritas pajak berada dalam relasi yang setara (Braithwait, 2002). Hal ini juga menunjukkan bahwa pemerintah telah merubah perspektif terkait kepatuhan dimana terjadi perubahan perspektif kepatuhan tradisional dimana posisi otoritas pajak dianggap lebih superior daripada wajib pajak menjadi relasi dengan suatu mitra yang setara (OECD, 2010). Jika direfleksikan dengan bagaimana Norwegia menjalankan sistem perpajakannya sehubungan dengan relasi wajib pajak dan pemungut pajak, maka langkah yang diambil oleh pemerintah Indonesia dapat 
dikatakan telah mengikuti tren perubahan paradigma global.

Ketika Indonesia berupaya menarik investor dengan memberikan insentif pajak dan mendirikan area industri di suatu wilayah tertentu untuk menarik investor, maka hal tersebut merupakan suatu kelaziman, seperti hal yang dilakukan oleh Norwegia. Namun, tentu pemberian insentif tersebut disesuaikan dengan kebutuhan domestic serta seyogiyanya pemberian insentif tersebut tidak menyebabkan unnecessary tax expenditure (Redonda, 2016). Dalam decade terakhir, pemerintah Indonesia justru memberikan insentif fiskal yang sangat excessive. Justru hal ini tidak sejalan dengan komitmen Indonesia dalam menjalankan BEPS Inclusive Framework, yaitu terkait harmful tax competition dimana pemberian insentif pajak yang demikian eksesif dikhawatirkan menciptakan persaingan pajak dengan negara tetangga di khawasan regional yang sama dengan Indonesia (Rosdiana and Tambunan, 2019).

Selain itu, dikhawatirkan juga dengan insentif yang berlebihan akan menggerus penerimaan pajak sementara akan mengorbankan sumber pendanaan untuk menyediakan layanan public yang dibutuhkan oleh pemerintah secara berkesinambungan. Pilihan kebijakan yang demikian justru akan menyalahi prinsip pemerataan (income distribution) melalui layanan publik yang menjadi tugas pemerintah. Ketika Norwegia menetapkan kebijakan insentif, kebijakan tersebut telah dirancang sedemikian antisipatif sehingga tidak mendorong terjadinya harmful tax competition dengan negara tetangga yang berada dalam suatu kawasan regional dan tetap berpedoman pada prinsip income redistribution.

Selanjutnya, terkait pemungutan dan administrasi perpajakan, penggunaan data atau big data dalam penggalian potensi pajak, adanya tax amnesty merupakan salah satu sarana atau langkah awal namun cukup penting dalam penghimpunan informasi tekait potensi penggalian penerimaan pajak. Namun, apakah terdapat akselerasi penggalian potensi yang cukup signifikan dari adanya tax amnesty masih menjadi suatu catatan penting. Penggunaan big data di era digital saat ini adalah suatu keniscayaan. Hingga saat ini bagaimana tindak lanjut setelah berakhirnya tax amnesty berbagai wacana terkait tersebut masih terus hadir dalam ruang publik (Saeroji, 2017; Binis Indonesia, 2019). Terkait bagaimana mengoptimalkan data sebagai tool untuk menggali potensi perpajakan masih terus menjadi pekerjaan rumah otoritas pajak Indonesia. Salah satu kunci penggalian potensi pajak sekaligus monitoring kepatuhan yang dilakukan oleh pemerintah Norwegia justru mengoptimalkan teknologi dan big data sebagai tulang punggung.

Jika melihat kembali perjalanan reformasi perpajakan di Indonesia, jika menggunakan kacamata pemerintah, proses reformasi ini dikatakan cukup berhasil membentuk suatu tatanan sistem perpajakan yang modern (Putra, 2014). Namun, dalam hal outcomes yang diukur dengan kemampuan memungut pajak, pada kenyatannya tidak terdapat perubahan signfikan dalam kurun satu decade terakhir dengan kemampuan pemungutan pajak yang masih ada dalam rata-rata $12 \%$ sementara sementara negara berkembang lainnya seperti Malaysia dan Thailand telah memiliki tax ratio yang lebih tinggi (ADB, 2019). Studi yang dilakukan oleh OECD pada tahun 2019 menyebutkan bahwa wajib pajak Indonesia mengalami peningkatan, namun tidak dibarengi dengan peningkatan penerimaan sector perpajakan. Hal ini perlu menjadi bahan evaluasi selanjutnya untuk dapat meningkatkan kapasitas pemajakan administrasi perpajakan Indonesia.

\section{KESIMPULAN DAN SARAN}

Pemerintah Norwegia merancang sedemikian rupa agar sistem perpajakannya tidak semata-mata ditujukan untuk memenuhi anggaran penerimaan. Bahkan, lebih jauh, digunakan sebagai instrumen tranformasi yang mempengaruhi kegiatan ekonomi, produktivitas dan pertumbuhan. Dengan demikian, dapat dikatakan bahwa transfornasi yang diharapkan oleh Norwegia atas reformasi perpajakannya adalah semakin besarnya peranan sistem perpajakan sebagai instrumen pembiayaan pemerintah serta pemerataan kemakmuran, yaitu sebagai sarana distribusi dengan berbagai mekanisme, terlepas dari masih tersisanya beberapa pekerjaan rumah pemerintah Norwegia. Selain itu, pemungutan pajak juga didorong untuk mengoptimalkan prinsip minimalisir unnecessary high administrative cost, baik bagi wajib pajak, maupun bagi otoritas pajak dengan mengoptimalkan teknologi serta mengoptimalkan kemampuan kapasitas institusi administrasi perpajakannya.

Indonesia saat ini telah melakukan berbagai perbaikan dalam sistem perpajakannya. Reformasi perpajakan yang dimulai sejak 1983 telah membentuk wajah baru sistem perpajakan Indonesia. Dibentuknya berbagai UU baru terkait pajak penghasilan dan PPN merupakan bentuk dari keikutsertaan Indonesia dalam tren perpajakan global. Secara spesifik adanya kebijakan penurunan tarif Pajak Penghasilan dan ditawarkannya berbagai insentif juga merupakan bukti bahwa Indonesia turut serta dalam tren reformasi pajak global. Dalam hal administrasi, pemerintah Indonesia berupaya untuk melaksanakan tugasnya dengan berfokus pada prinsip pelayanan dan kesetaraan dengan wajib pajak. Namun, pada kenyatannya masih terdapat berbagai pekerjaan rumah lainnya terutama terkait peningkatan kepatuhan pajak, penggalian potensi pajak berbasis big data serta monitoring basis penerimaan pajak untuk menghindari penggerusan akibat kebijakan yang terlalu agresif. 


\section{IMPLIKASI DAN KETERBATASAN}

Penelitian terkait perjalanan reformasi perpajakan ini menggunakan dua lokus negara yang sangat berbeda terutama terkait kapasitas ekonomi, jumlah penduduk dan luas wilayah. Adanya perbedaan mendasar tersebut akan menghasilkan temuan yang sangat berbeda yang menjadi catatan penting dalam penelitian ini. Namun, yang menjadi penekanan dalam tulisan ini adalah memberikan suatu gambaran bagaimana suatu proses reformasi perpajakan telah mampu menghasilkan sistem perpajakan yang berfungsi sebagai instrument pemerataan ekonomi yang bersifat berkesinambungan serta bagaimana reformasi tersebut ditopang oleh administrasi perpajakan yang kuat.

\section{DAFTAR PUSTAKA (REFERENCES)}

\section{Buku dengan Pengarang Tunggal:}

Creswell J.W. (2003) Research Design: Qualitative, Quantitative and Method Approach. California: Sage Publication Inc.

Royal Ministry of Finance, (2014), The Norwegian Tax System, Main Features and Developments, Chapter 2 of the Budget Proposal on Taxes 2015, Oslo Norway

Tanzi V. (1995), Taxation in an Integrated World, Washington DC: The Brookings Institute.

Valeria Braithwaite (2002) A New Approach to Tax Compliance, Ashgate Publishing Ltd

\section{Buku dengan dua pengarang:}

Atkinson A. dan Stiglitz J., (1980) Lectures on Public Finance, London, McGraw-Hill.

\section{Jurnal dan Laporan Penelitian}

Azemar C. and Dharmapala D., (2018) Tax Sparing Agreements, Territorial Tax Reforms and Foreign Direct Investment, World bank Publication.

Christiansen Vidar, (2004), Norwegian Income Tax Reform, University of Olso CESifo DICE Report $3 / 2004$.

Christine Lewis (2019) Raising more public revenue in Indonesia in a growth and equity friendly way, OECD Economic Department Working Papers No. 1534.

Eureka Putra (2014) A Study of the Indonesia's Income Tax Reform and the Development of Income Tax Revenues, Journal of East Asian Studies, No. $12,2014.3$ pg. 55-68.
Fuad Bawazier, 2011, Reformasi Pajak di Indonesia, Jurnal Legislasi Indonesia, Vol. 8 No. 1, April 2011. Hal 1-4,

Hansson Asa, (2010) Is the Wealth Tax Harmful to Economic Growth? World Tax Journal Ed. Feb 2010, International Bureau of Fiscal Documentation.

IMF (2017) Norway: Selected Issue, IMF Country Report No. 17/181.

IMF Working Paper, (2016), Political Institutions, State Building, and Tax Capacity: Crossing the Tipping Point, WP/16/233.

Kristian Agung Prasetyo (2018) Tax Administration Reform and the Society in Indonesia: Some Lesson Learnt, retrieved from https://www.business.unsw.edu.au/AboutSite/Schools-Site/Taxation-Business-LawSite/Documents/Tax_Administration_Reform_ and_the_Society_in_Indonesia_Prasetyo.pdf.

Mohamad Ikhsan, Ledi Trialdi and Syarif Syahrial, 'Indonesia's New T ax Reform: Potential and Direction' (2005) 16(6) Journal of Asian Econom ics1029.

Riskjell O.K., (2014) A Fundamental Tax Reform in Norway, A Comparison of the Allowance for Corporate Equity System and the Comprehensive Business Income Tax ystem in a Norwegian Setting, Norwegian School of Economy Universite Catholique de Louvain.

Rubolino E and Waldernstorm D. (2019) Tax Progressivity and Top Incomes: Evidence from Tax Reform, Institute for Social and Economic Research (ISER).

Tuan Minh Le, Blanca Moreno-Dodson and Nihal Bayraktar, 'Tax Capacity and T ax Effort: Extended Cross-Country Analysis from 1994 to 2009' (2012) Policy Research Working Paper No 625.

Oliver Denk, (2012) Tax Reform in Norway: A Focus on Capital Taxation, OECD Economics Department Working Papers No. 950, retrieved from https://www.oecd-ilibrary.org/economics/taxreform-in-norway_5k9bls0vpd5d-en.

OECD (2017) Economic Policy Reforms 2017: Going for Growth Norway 2017.

OECD (2016) Consumption Tax Trend 2016 in Norway.

OECD (2016) Technologies for Better Tax Administration: A Practical Guide for Revenue Bodies.

OECD (2012) Tax Reform in Norway: A Focus on Capital Taxation, OECD Economics Department Working Papers No.950

Onstad-Gjems Ole (2012) Tax Competition in Europe, Norway National Report, European Association of Tax Law Professor Report

Onstad-Gjems Ole (2012) Direct Taxation: Income and Net Wealth Taxation National Report, 
European Association of Tax Law Professor Report.

Pelaka Maciej, (2013), The Future of Personal Wealth Tax and Inheritance Taxation in Norway, Department of Economics University of Oslo.

Princen S., (2012) Taxes do Affect Corporate Financing Decisions: The Case of Belgian ACE, CESifo, Louvain-la-Neuve: CESifo.

Rahayu Ning (2010) Evaluasi Regulasi atas Praktik Penghindaran Pajak Penanaman Modal Asing, Jurnal Akuntansi dan Keuangan Indonesia Vol. 7 No.1, Juni 2010, hal 61-78

Rosdiana, Tambunan and Irianto (2019) Review of Implementation of the Inclusive Framework on Base Erosion and Profit Shifting in Indonesia, Intertax Vol, Issue 6/7 pp. 635-651.

Redonda Agustine, (2016) Tax Expenditure and Sustainability: An Overview, Council on Economic Policy, retrieved from https://www.cepweb.org/wpcontent/uploads/CEP-DN-Tax-Expendituresand-Sustainability.-An-Overview.pdf.
Schjelderup G.,(2012) Multinationals and Transfer Pricing, Bergen, Norwegia: Norwegian School of Economy Universite Catholique de Louvain. Valkonen T and Vihriala V. (2014) The Nordic Model Challenge but Capable of Reform, Nordic Council of Ministers.

\section{Website:}

Bisnis Indonesia (2019) Tindak Lanjut Amnesti Indonesia: Ditjen Pajak Agresif Berburu, diunduh dari https://www.ssas.co.id/tindaklanjut-amnesti-pajak-ditjen-pajak-agresifberburu/.

Kementerian Keuangan https://www.kemenkeu.go.id/publikasi/berita/ tax-holiday-melalui-pmk-35pmk0102018mulai-dorong-investasi/.

Saeroji Oji, (2017) Setelah Amnesti Pajak Berakhir, diunduh dari https://www.pajak.go.id/id/artikel/setelahamnesti-pajak-berakhir 